\title{
KEMAMPUAN MENGANALISIS UNSUR INTRINSIK KARYA SASTRA
}

\author{
Cita Hikmah Yanti ${ }^{1}$, Neisya ${ }^{2}$ \\ Dosen Universitas Bina Darma ${ }^{1}$, Dosen Universitas Bina Darma ${ }^{2}$ \\ Jalan Jenderal Ahmad Yani No. 3 Palembang
}

Sur-el: citahikmahyanti@binadarma.ac.id ${ }^{1}$, neisya@binadarma.ac.id ${ }^{2}$,

Article info

Article history:

Received: 30-05-21

Revised : 05-06-21

Accepted: 20-06-21

Keywords:

$C A R$, intrinsic

elements, literature

Kata Kunci:

PTK, unsur

interinsik, karya

sastra

\begin{abstract}
A B S T R A C T
This study aims to evaluate the teaching of literary appreciation in improving the ability to analyze the intrinsic elements of a literary work. The object of this research is the 3rd semester students of the English Literature Study Program, Faculty of Teacher Training and Education and Language Sciences at Universitas Bina Darma. This study uses the CAR method (class action research) where this method has 3 cycles. In each cycle, researchers and teachers will evaluate the results of teaching in each cycle to be improved in the next cycle. In this study, the intrinsic elements that will be analyzed by students are the theme, setting, characterizations, plot, point of view, message and style of language. By using the methods and teaching materials that have been prepared in the third cycle, researchers and teachers have been able to significantly improve the ability to analyze the intrinsic elements of a literary work.
\end{abstract}

Penelitian ini bertujuan untuk mengevaluasi pengajaran apresiasi karya sastra dalam meningkatkan kemampuan menganalisis unsur interinsik dari sebuah karya sastra. Objek penelitian ini adalah mahasiswa semester 3 program studi sastra Inggris fakultas keguruan dan ilmu Pendidikan dan Bahasa di Universitas Bina Darma. Penelitian ini menggunakan metode PTK (penelitian tindak kelas) dimana metode ini memiliki 3 siklus. Dalam setiap siklus peneliti dan pengajar akan sama-sama mengevaluasi hasil pengajaran di setiap siklus untuk diperbaiki pada siklus selanjutnya. Pada penelitian ini, unsur intrinsik yang akan dianalisis oleh mahasiswa adalah tema, latar, tokoh penokohan, alur, sudut pandang, amanat dan gaya bahasa. Dengan menggunakan metode dan bahan ajar yang telah disiapkan pada siklus ke3 peneliti dan pengajar telah secara signifikan mampu meningingkatkan kemampuan analisis unsur interinsik sebuah karya sastra.

Direktorat Riset dan Pengabdian Masyarakat Universitas Bina Darma. 


\section{JURNAL ILMIAH \\ BINA EDUKASI \\ ISSN 1979-8598 E-ISSN: 2655-8378 \\ http://journal.binadarma.ac.id/index.php/jurnalbinaedukasi \\ Vol. 14, No. 1, Juni 2021, $69-80$}

\section{PENDAHULUAN}

Karya sastra adalah bentuk ekspresi pemikiran manusia yang dituangkan dalam berbagai bentuk sedari ratusan tahun yang lalu dan berperan penting dalam peradaban manusia. Karya sastra menjadi salah satu cara manusia mengekspresikan pengalaman, pendapat, dan pengetahuan yang dimiliki untuk dikomunikasikan kembali kepada para penikmat sastra dengan tambahan nilai estetik di dalamnya. Sastra pun dikembangkan sesuai dengan kebutuhan manusia dalam mencapai peradaban. Bahkan menurut Rahmanto (2005), menyebutkan bahwa pembelajaran sastra dapat membantu keterampilan berbahasa anak, meningkatkan pengetahuan budaya, mengembangkan cipta dan rasa, serta menunjang pembentukan watak

Pencipta karya sastra juga telah berinovasi dalam penyajian sastra, sehingga sastra tidak hanya sekedar bidang ilmu namun telah menjadi salah satu unsur kebudayaan yang berjalan mengiringi peradaban. Menurut Harsanti (2015) fungsi utama sastra adalah sebagai penghalusan budi, peningkatan rasa kemanusiaan dan kepedulian sosial, penumbuhan apresiasi budaya, dan penyalur gagasan, imajinasi, dan ekpresi secara kreatif dan konstruktif. Menilai dari petingnya sastra dalam kehidupan, maka sastra menjadi salah satu unsur pengembang pendidikan.

Karya sastra mempunyai relevansi dengan masalah-masalah dunia pendidikan dan pengajaran. Ia dapat membukakan mata pembaca untuk mengetahui realitas sosial, politik dan budaya dalam bingkai moral dan estetika. Dari dulu sampai sekarang karya sastra tidak pernah pudar dan mati. Dalam kenyataan tulisan kreatif ini dapat dipakai untuk mengembangkan wawasan berpikir bangsa. Hal inilah yang menyebabkan perlunya sastra sebagai media pembelajaran dalam pendidikan.

Relasi antara sastra dan pendidikan, khususnya dalam pembentukan kepribadian peserta didik dapat ditinjau dari merosotnya nilai-nilai dan norma sosial yang berakibat pada maraknya isu sosial seperti, narkoba, seks bebas, vandalisme, minuman keras, tawuran dan banyak lagi. Hal ini menegaskan bahwa pendidikan tidak hanya tentang ilmu eksakta saja, namun pendidikan karakter pada peserta didik pun perlu dipertimbangkan.

Tujuan pengajaran sastra sebenarnya memiliki dua sasaran, yaitu agar mahasiswa memperoleh pengetahuan dan pengalaman sastra. Pertama, pengetahuan sastra diperoleh dengan membaca teori, sejarah, dan kritik sastra. Kedua, pengalaman sastra dengan cara membaca, melihat pertunjukan karya sastra, dan menulis karya sastra. Sedangkan aplikasinya dalam mengajar bahasa Indonesia atau apresiasi karya sastra harus memperoleh pengetahuan yang berangkat dari pengalaman karya sastra. Artinya, untuk mengajarkan sastra, dosen harus mampu memberikan pengalaman berdasarkan karya sastra tersebut. Sebagai contoh, untuk memperoleh teori tentang unsur-unsur dalam roman/novel atau karya sastra lain, seorang dosen harus memperkenalkan roman/novel dengan cara mengkaji dan mengapresiasinya. 


\section{JURNAL ILMIAH \\ BINA EDUKASI \\ ISSN 1979-8598 E-ISSN: 2655-8378 \\ http://journal.binadarma.ac.id/index.php/jurnalbinaedukasi \\ Vol. 14, No. 1, Juni 2021, $69-80$}

Kegiatan membaca dan mengapresiasikan karya sastra merupakan salah satu bagian dari aktivitas kehidupan manusia. Ketika pembaca mengapresiasikan salah satu judul cerpen atau cerita pendek, setelah pembaca melaksanakan kegiatan membaca terhadap keseluruhan cerpen itu, pembaca lebih lanjut menampilkan pertanyaan-pertanyaan, misalnya cara penokohannya, setting-nya, perwatakan setiap tokoh dan pertanyaan tentang unsur intrinsik lain yang terdapat dalam cerpen itu. Pembaca kemudian kembali membaca ulang sambil berusaha menganalisis setiap unsur yang telah ditetapkannya yang paling penting yaitu cara melukiskan kemampuan mahasiswa dalam menggunakan bahasa Indonesia untuk memahami unsur-unsur intrinsik dalam salah satu hasil karya sastra. Hal ini menunjukkan, bahwa karya sastra (cerpen) memiliki beberapa muatan yang berguna bagi masyarakat. Dengan adanya langkah- langkah ini, maka perkembangan sastra Indonesia akan mengalami kemajuan yang pesat.

Berdasarkan hasil pengamatan terhadap proses belajar-mengajar di kelas, peneliti menemukan beberapa permasalahan yang terjadi, baik pada diri dosen maupun mahasiswa khususnya dalam menganalisis unsur intrinsik cerpen. Pada saat proses belajar- mengajar berlangsung khususnya ketika mahasiswa diperintahkan untuk menganalisis unsur intrinsik cerpen yang terdapat dalam cerpen, mereka mengalami kesulitan dalam menemukan unsur intrinsik tersebut karena selama ini mahasiswa hanya diberikan pengetahuan tentang teori pengertian dari tema, penokohan, amanat, latar dan juga sudut pandang.

Selain itu, tidak dijelaskan juga cara menentukan unsur-unsur tersebut. Mahasiswa juga tidak terlalu serius membaca cerpen, dan kebanyakan mengobrol dengan teman sebangkunya, bersenda gurau dengan temannya. Kondisi belajar yang seperti ini dapat mengakibatkan hasil belajar yang diharapkan jauh dari nilai standar, dan mahasiswa menganggap pelajaran menganalisis unsur intrinsik cerpen ini merupakan pelajaran yang membosankan. Mereka pun menjadi malas untuk mengikuti pelajaran ini. Hal ini disebabkan oleh kurangnya kemampuan dosen tersebut dalam melaksanakan pembelajaran inovatif untuk meningkatkan motivasi belajar mahasiswa.

Mengacu pada paparan di atas, dapat diidentifikasi penyebab rendahnya kemampuan mahasiswa dalam menganalisis unsur intrinsik cerpen yaitu disebabkan oleh dosen yang kurang mampu menerapkan metode pembelajaran yang inovatif untuk memotivasi mahasiswa meningkatkan kreatifitas dan aktivitas dalam menganalisis unsur intrinsik cerpen. Selama ini pembelajaran yang dilaksanakan cenderung menoton dan hanya menitikberatkan pada pengertian dan teori tanpa ada praktek langsung proses dalam memecahkan suatu permasalahan yang dihadapi.

Untuk itu dalam pembelajaran diperlukan metode yang sesuai dengan tingkat perkembangan mahasiswa. Dengan demikian, pemilihan metode yang tepat dan efektif sangat diperlukan. Sebagaimana pendapat Sudjana (2001), bahwa peranan metode mengajar sebagai alat 


\section{JURNAL ILMIAH \\ BINA EDUKASI \\ ISSN 1979-8598 E-ISSN: 2655-8378 \\ http://journal.binadarma.ac.id/index.php/jurnalbinaedukasi \\ Vol. 14, No. 1, Juni 2021, 69 - 80}

untuk menciptakan proses belajar dan mengajar. Oleh karena itu, dalam penelitian ini peneliti menggunakan metode diskusi kelompok kecil.

Tujuan utama metode diskusi jenis ini adalah untuk mengetahui sejauh mana keaktifan dan kemampuan dosen, keterampilan kooperatif mahasiswa, keterampilan dosen dalam mengelola pembelajaran, dan hasil belajar mahasiswa pada pokok bahasan perbandingan dan fungsi trigonometri dengan diterapkannya pembelajaran kooperatif menggunakan metode diskusi.

\section{METODOLOGI PENELITIAN}

Pada penelitian ini, metode yang digunakan adalah penelitian tindak kelas (PTK). PTK adalah suatu bentuk penelitian yang bersifat refleksif dengan melakukan perlakuan (treatment) tertentu untuk menghasilkan peningkatan terhadap pembelajaran yang dipraktekan di dalam kelas. Menurut Kemmis \& McTaggart (1988) penelitian tindakan adalan studi yang dilakukan untuk memperbaiki diri sendiri, pengalaman kerja sendiri tetapi dilaksanakan secara sistematis, terencana dan dengan sikap mawas diri. Dalam pelaksanaannya, PTK dilakukan dengan menerapkan perlakuan pada beberapa siklus, dalam hal ini pada pembelajaran menganalisis unsur intrinsik oleh mahasiswa semester 3 Program Studi Sastra Inggris Fakultas Keguruan, Ilmu Pendidikan, dan Bahasa Universitas Bina Darma Palembang.

Subjek dalam penelitian ini adalah mahasiswa semester 3 Program Studi Sastra Inggris Fakultas Keguruan, Ilmu Pendidikan, dan Bahasa Universitas Bina Darma Palembang yang berjumlah 15 orang. Selanjutnya, tujuan penelitian ini adalah peningkatan kemampuan menganalisis unsur intrinsik karya sastra melalui metode diskusi.

Adapun PTK ini menggunakan model Kurt Lewin (dalam Nurhalim, 2000) yang telah diterapkan selama 3 siklus dalam studi ini adalah sebagai berikut:

1. Tahap perencanaan (plan)

Hal pertama yang wajib dilakukan oleh pengajar yaitu menyusun rencana akan hal-hal yang hendak dilakukan selama PTK berlangsung. Dalam penelitian ini, pengajar dan peneliti merencanakan metode pengajaran dan bahan ajar serta bahan evaluasi untuk melihat peningkatan kemampuan analisis mahasiswa. Pada tahap awal ini, peneliti mencari informasi tentang keadaan mahasiswa dan menguraikan metode dan prosedur yang dilakukan selama PTK berlangsung. Peneliti juga bekerjasama dengan pengajar untuk mengetahui informasi tentang motivasi, gaya belajar dan hasil belajar mahasiswa yang telah terdokumentasi dalam rubrik yang tersedia dan pengamatan langsung di dalam kelas. Hal ini diperlukan sehingga peneliti dapat menyiapkan bahan ajar, dan media pembelajaran yang sesuai, Menyusun instrumen evaluasi seperti Pre-test dan Post-tes serta lembar observasi. 


\section{JURNAL ILMIAH \\ BINA EDUKASI \\ ISSN 1979-8598 E-ISSN: 2655-8378 \\ http://journal.binadarma.ac.id/index.php/jurnalbinaedukasi \\ Vol. 14, No. 1, Juni 2021, $69-80$}

\section{Pelaksanaan Tindakan.}

Pada Langkah ini, peneliti melaksanakan semua rencana yang telah dibuat, peneliti mengamati kesesuaian antara rencana dan pelaksanaan, proses pelaksananaan berlangsung lancar atau tidak, mengamati situasi proses selama di kelas tentang bagaimana sikap mahasiswa dan motivasi belajar selama kegiatan berlangsung. Berikut kegiatan yang dilakukan di dalam kelas:

a. Kegiatan pendahuluan: pengajar menjelaskan tujuan pembelajaran, materi pembelajaran, dan memberikan pre-test.

b. Kegiatan inti: pengajar menerapkan metode pengajaran yang telah dilaksanakan, yaitu memberikan bahan bacaan berupa karya sastra, memberi waktu mahasiswa untuk membaca dan berdiskusi dengan grup kelas dan meminta para mahasiswa untuk mencari unsur interinsik dalam karya sastra yang mereka baca.

c. Kegiatan penutup: pengajar memberikan bahan bacaan dan memberikan tugas individu dan menilai hasil analisis mereka (post-test).

3. Pengamatan

Pada tahap ini, peneliti berkerja sama dengan pengajar untuk menilai hasil pre-test sebagai tolak ukur kemampuan awal mahasiswa, lalu mengamati rubrik peneliti yang telah diisi berdasarkan pengamatan di dalam kelas selama tindakan (treatment) berlangsung. Dan terakhir adalah mengamati hasil post-test mahasiswa sebagai tolak ukur peningkatan kemampuan mahasiswa dalam menganalisis unsur intrinsik karya sastra.

Unsur intrinsik sebuah karya sastra bertujuan untuk meningkatkan minat baca, meningkatkan apresiasi terhadap karya sastra, serta memotivasi pembaca untuk berpikir kritis. Unsur intrinsik merupakan unsur pembangun karya sastra yang berasal dari dalam karya itu sendiri. Pada novel Nurgianto (2009) menjelaskan unsur intrinsik itu berupa:

1. Tema: merupakan dasar cerita atau gagasan umum dari sebuah novel.

2. Plot: merupakan hubungan antarperistiwa yang bersifat sebab akibat, tidak hanya jalinan peristiwa secara kronologis.

3. Penokohan: Penokohan dalam novel adalah unsur yang sama pentingnya dengan unsur-unsur yang lain. Penokohan adalah teknik bagaimana pengarang menampilkan tokoh-tokoh dalam cerita sehingga dapat diketahui karakter atau sifat para tokoh (Siswandarti, 2009)

4. Latar: Latar menurut Abrams (1981) adalah landasan atau tumpuan yang memiliki pengertian tempat, hubungan waktu, dan lingkungan sosial tempat terjadinya peristiwa-peristiwa yang diceritakan.

5. Sudut pandang: Unsur intrinsik karya fiksi berikutnya adalah sudut pandang. Nurgiyantoro (2009) berpendapat bahwa sudut pandang adalah cara penyajian cerita, peristiwa-peristiwa, dan tindakan-tindakan pada karya fiksi berdasarkan posisi 


\section{JURNAL ILMIAH \\ BINA EDUKASI \\ ISSN 1979-8598 E-ISSN: 2655-8378 \\ http://journal.binadarma.ac.id/index.php/jurnalbinaedukasi \\ Vol. 14, No. 1, Juni 2021, 69-80}

pengarang di dalam cerita.

6. Gaya Bahasa: Bahasa sesuai dengan pendapat Siswandarti (2009) merupakan jenis bahasa yang dipakai pengarang, sebagai contoh misalnya gaya pop untuk remaja, gaya komunikatif, atau jenis bahasa yang kaku (seperti pada cerita terjemahan). Nurgiyantoro (2009) juga berpendapat bahwa bahasa merupakan sarana pengungkapan yang komunikatif dalam sastra.

7. Amanat: Amanat atau nilai moral merupakan unsur isi dalam karya fiksi yang mengacu pada nilai-nilai, sikap, tingkah laku, dan sopan santun pergaulan yang dihadirkan pengarang melalui tokoh-tokoh di dalamnya (Kenny, 1966).

Adapun PTK yang diterapkan dalam studi ini yaitu setiap siklus dalam penelitian ini dilaksanakan berdasarkan hasil kolaborasi dan refleksi setelah satu tindakan dilaksanakan. Untuk mengetahui kemampuan awal mahasiswa, maka dilaksanakan pre-test. Pelaksanaan penelitian dengan menggunakan metode diskusi terdiri atas perencanaan (planning), tindakan (acting), pengamatan (observasi) danrefleksi (reflecting). Penelitian tindakan kelas ini rencananya akan dilakukan hingga siklus ke 3. Adapun target menganlisis karya sastra ini adalah mahasiswa dapat mencapai nilai 75 dimana nilai tersebut merupakan nilai minimal untuk mencapai nilai B (baik) yang telah ditentukan oleh pihak Universitas Bina Darma. Dalam perencanaannya, peneliti menggunakan: (1) tiga karya sastra yaitu cerita pendek (short story), drama dan novel sebagai objek analisis dalam mencari unsur interinsik, (2) mempersiapkan rencana penelitian tindak kelas dan pengajaran nya), (3) mempersiapkan evaluasi pada tiap-tiap siklus.

Analisis data tes secara kuantitatif dihitung dengan cara persentase melalui langkahlangkah sebagai berikut:

1. Menilai hasil penilaian di tiap siklus dari setiap mahasiswa berdasarkan rubrik berikut:

Tabel 1. Kompetensi Mahasiswa Setiap Komponen Unsur Intrinsik

\begin{tabular}{lll}
\hline No. & Unsur & Kompetensi \\
\hline 1 & Tema & $\begin{array}{l}\text { Mampu memahami gagasan utama dari sebuah } \\
\text { cerita dengan baikdari keseluruhan cerita }\end{array}$ \\
\hline 2 & Latar & $\begin{array}{l}\text { Mampu memahami latar kejadian dalam sebuah } \\
\text { cerita, seperti waktu, tempat, sosial budaya, } \\
\text { keadaan lingkungan, dan suasana. }\end{array}$ \\
\hline 3 & Tokoh dan Penokohan & $\begin{array}{l}\text { Memahami dengan baik tokoh yang terlibat dalam } \\
\text { cerita serta karakter/penokohan yang digambarkan } \\
\text { oleh penulis, baik dari dialog, narasi cerita maupun } \\
\text { gambaran fisik tokoh tersebut }\end{array}$ \\
& & $\begin{array}{l}\text { Mampu menyebutkan bagian cerita dengan tahapan } \\
\text { perkenalan, penanjakan, klimaks, antiklimaks, dan }\end{array}$ \\
& Alur & penyelesaian. Serta memahami jenis jalan cerita \\
& & yang digunakan oleh penulis \\
\hline 5 & Sudut Pandang & Mampu memahami strategi penulis dalam \\
& & menceritakan apa yg tertulis dalam sebuah karya \\
\hline
\end{tabular}




\begin{tabular}{lll}
\hline & & $\begin{array}{l}\text { sastra serta memahami jenis sudut pandang yang } \\
\text { digunakan penulis (orang pertama, kedua, atau } \\
\text { ketiga) }\end{array}$ \\
\hline 6 & Amanat & $\begin{array}{l}\text { Mampu menyimpulkan dengan baik makna atau } \\
\text { pesan moral yang tersirat dalam sebuah cerita. }\end{array}$ \\
\hline 7 & Gaya Bahasa & $\begin{array}{l}\text { Memahami penggunaan dan jenis majas dan diksi } \\
\text { dalam sebuah cerita. }\end{array}$ \\
\hline
\end{tabular}

2. Merekap nilai tersebut dengan konversi nilai yang berlaku di Universitas Bina Darma, yaitu:

Tabel 2. Konversi Nilai

\begin{tabular}{lll}
\hline No & Nilai & Huruf \\
\hline $\mathbf{1}$ & $85-100$ & A \\
\hline $\mathbf{2}$ & $75-84$ & B \\
\hline $\mathbf{3}$ & $65-74$ & C \\
\hline $\mathbf{4}$ & $55-64$ & D \\
\hline $\mathbf{5}$ & $0-54$ & E \\
\hline
\end{tabular}

3. Menentukan rata-rata nilai dalam setiap siklus tindakan kelas.

4. Mengamati perkembangan kemampuan mahasiswa dalam menganalisis unsur interinsik cerita.

\section{HASIL DAN PEMBAHASAN}

\subsection{Siklus 1}

Pada tahap pertama dalam PTK, pengawas dan pengajar telah mendiskusikan hal-hal yang terjadi didalam proses pengajaran selama ini. Sehingga mereka telah bekerjasama dalam menentukan metode pembelajaran yang akan diaplikasikan selama penelitian. Lalu merencanakan materi belajar yang cukup beragam dan menarik dan dan evaluasi pembelajaran yang mencakup keseluruhan kegiatan pembelajaran. Kemudian, pengawas dan pengajar membuat persiapan tersebut tersusun rapi dalam perencanaan penelitian tindak kelas ini.

Dalam studi ini terdapat tiga siklus. Pada siklus pertama, Pengajar dan pengawas menggunakan metode small group discussion karena materi yang digunakan adalah novel Khaled Hosseini yang diterbitkan pada tahun 2003. Novel ini merupakan novel kompleks yang diyakini memiliki unsur interinsik yang menarik, sehingga dapat menarik minat para mahasiswa dalam membaca novel tersebut. Berikut skor mahasiswa dalam menganalisis unsur interinsik sebuah novel. 
Tabel 3. Nilai rata-rata Analisis Unsur Interinsik Mahasiswa Siklus 1

\begin{tabular}{|c|c|c|c|c|c|c|c|c|c|c|c|c|c|c|c|c|}
\hline \multirow{2}{*}{$\begin{array}{c}\text { Unsur } \\
\text { Interinsik }\end{array}$} & \multicolumn{15}{|c|}{ Mahasiswa } & \multirow{2}{*}{$\begin{array}{l}\text { Rata- } \\
\text { Rata }\end{array}$} \\
\hline & A & B & $\mathrm{C}$ & $\mathrm{D}$ & $E$ & $\mathrm{~F}$ & $\mathrm{G}$ & $\mathrm{H}$ & I & $\mathrm{J}$ & $\mathrm{K}$ & $\mathrm{L}$ & $\mathrm{M}$ & $\mathrm{N}$ & $\mathrm{O}$ & \\
\hline Tema & 50 & 55 & 60 & 55 & 60 & 70 & 70 & 70 & 65 & 60 & 60 & 60 & 50 & 55 & 70 & 60,7 \\
\hline Latar & 55 & 55 & 60 & 55 & 60 & 75 & 75 & 75 & 55 & 55 & 65 & 60 & 60 & 55 & 70 & 62 \\
\hline $\begin{array}{l}\text { Tokoh dan } \\
\text { Penokohan }\end{array}$ & 55 & 65 & 60 & 60 & 60 & 70 & 70 & 75 & 60 & 55 & 60 & 60 & 60 & 60 & 70 & 62,7 \\
\hline Alur & 55 & 60 & 60 & 50 & 55 & 70 & 60 & 75 & 55 & 55 & 60 & 60 & 60 & 50 & 70 & 59,7 \\
\hline Sudut Pandang & 55 & 55 & 65 & 60 & 60 & 75 & 70 & 70 & 60 & 55 & 60 & 55 & 65 & 60 & 75 & 62,7 \\
\hline Amanat & 50 & 60 & 55 & 60 & 70 & 70 & 70 & 70 & 65 & 60 & 65 & 60 & 55 & 60 & 75 & 63 \\
\hline Gaya Bahasa & 55 & 65 & 60 & 60 & 60 & 60 & 75 & 70 & 60 & 55 & 60 & 55 & 60 & 60 & 70 & 61,7 \\
\hline
\end{tabular}

Dapat dilihat pada tabel 3 di atas bahwa analisis yang dilakukan oleh mahasiswa belum mencapai standar kompetensi unsur interinsik sebuah karya sastra. Nilai rata- rata yang dihasilkan adalah 60,7 dan nilai individu terbesar adalah 70 (cukup) dan dihasilkan oleh 7 mahasiswa dari 15 mahasiswa, dimana skor ini bahkan belum termasuk kategori nilai Cukup (65-75). Menurut observer penelitian ini, hal ini disebabkan tema dalam novel tersebut kurang familiar dalam wawasan mahasiswa. Sehingga mereka tidak dapat menyimpulkan gagasan utama cerita tersebut.

Untuk unsur Latar, ada 3 mahasiswa yang telah memahami secara keseluruhan latar cerita dengan baik (skor 75), 1 mahasiswa mendapat nilai cukup (skor 70) 11 mahasiswa lain tidak dapat menganalisis latar dengan baik, dikarenakan mereka menganggap bahwa dalam sebuah cerita, latar hanya dideskripikan dari narasi tertulis, padahal dalam novel sekompleks ini, latar dideskripsikan dengan tersirat melalui keadaan sosial dan budaya serta kondisi lingkungan.

Untuk unsur Tokoh dan Penokohan, nilai rata-rata yang dihasilkan pada unsur ini adalah 62,7, 1 mahasiswa mendapat nilai 75 (baik), 3 lainnya mendapat nilai 70 (cukup). Sedangkan 11 lainnya mendapat nilai yang belum mencukupi. Hal ini disebab kan oleh pemahaman mahasiswa dalam menentukan karakter setiap tokoh masih belum baik. Namun untuk menyebutkan tokoh dalam cerita, mereka tidak memiliki masalah.

Pada unsur alur cerita, nilai rata-rata adalah 59,7. Dimana ada 1 mahasiswa mendapat nilai B (skor 75) dan 2 lagi mendapat nilai 70 (cukup), sedangkan 12 lainnya belum mendapat nilai yang cukup. Hal ini disebabkan pada novel ini memiliki alur kombinasi, yaitu alur maju dan mundur, namun mahasiswa belum dapat mendeskripsikan mana alur maju dan mundur.

Pada unsur sudut pandang, nilai rata-rata adalah 62,7 dimana 2 mahasisa telah cukup baik (skor 75) memahami unsur sudut pandang, 2 lainnya hanya memperoleh nilai cukup (skor 70). Sedangkan 11 lainya masih belum mencukupi nilainya. Hal ini disebabkan karena novel memiliki Bahasa yang lumayan kompleks sehingga sudut pandang masih sulit dipahami.

Pada unsur amanat, nilai rata-rata nya adalah 63. Ada 1 mahasiswa mendapat nilai 75 (baik) dan 4 orang lain mendapat nilai 70 (cukup). 10 orang lain belum mendapatkan nilai yang 


\section{JURNAL ILMIAH \\ BINA EDUKASI \\ ISSN 1979-8598 E-ISSN: 2655-8378 \\ http://journal.binadarma.ac.id/index.php/jurnalbinaedukasi \\ Vol. 14, No. 1, Juni 2021, $69-80$}

cukup untuk unsur ini dikarenakan mereka belum dengan baik memahami makna yang tersirat atau pesan moral dari cerita yang mereka baca dan untuk unsur gaya bahasa, hanya ada 1 mahasiswa mendapat nilai baik (skor 75), 2 orang lain mendapat nilai cukup (skor 70), dan 12 orang lainnya mendapat nilai yang kurang mencukupi untuk unsur ini dikarenakan mahasiswa tersebut belum memahami pengertian dan jenis majas dan diksi yang digunakan oleh penulis pada cerita yang mereka baca.

\subsection{Siklus 2}

Setelah mengamati apa yang terjadi pada siklus 1, dilakukan beberapa perbaikan metode pengajaran, pengelolaan waktu dan juga materi pembelajaran. Pengajar dan observer pada siklus ini memilih mencari unsur interinsik dalam sebuah novel berjudul Ayah, karya Andrea Hirata. Selain novelnya lebih pendek, cerita dari novel ini memiliki unsur bahasa yang lebih ringan dan alur cerita yang lebih cocok bagi mahasiswa yang berusia remaja. Sehingga hasil penilaian unsur interinsik pada siklus 2 ini mengalami peningkatan.

Tabel 4. Nilai Rata-Rata Analisis Unsur Interinsik Mahasiswa Siklus 2

\begin{tabular}{|c|c|c|c|c|c|c|c|c|c|c|c|c|c|c|c|c|}
\hline \multirow{2}{*}{$\begin{array}{c}\text { Unsur } \\
\text { Interinsik }\end{array}$} & \multicolumn{15}{|c|}{ Mahasiswa } & \multirow{2}{*}{$\begin{array}{l}\text { Rata- } \\
\text { Rata }\end{array}$} \\
\hline & A & B & $\mathrm{C}$ & $\mathrm{D}$ & $E$ & $\mathrm{~F}$ & $\mathrm{G}$ & $\mathrm{H}$ & I & $\mathrm{J}$ & $\mathrm{K}$ & $\mathrm{L}$ & $\mathrm{M}$ & $\mathrm{N}$ & $\mathrm{O}$ & \\
\hline Tema & 70 & 70 & 70 & 70 & 70 & 70 & 70 & 70 & 70 & 70 & 65 & 70 & 60 & 65 & 75 & 69 \\
\hline Latar & 70 & 75 & 75 & 75 & 75 & 75 & 75 & 75 & 75 & 75 & 75 & 70 & 75 & 75 & 75 & 74,3 \\
\hline $\begin{array}{l}\text { Tokoh dan } \\
\text { Penokohan }\end{array}$ & 70 & 70 & 75 & 70 & 75 & 70 & 70 & 75 & 70 & 75 & 75 & 75 & 75 & 75 & 70 & 72,7 \\
\hline Alur & 70 & 60 & 70 & 70 & 75 & 70 & 60 & 75 & 70 & 70 & 70 & 70 & 70 & 70 & 70 & 69,3 \\
\hline Sudut Pandang & 70 & 75 & 75 & 75 & 75 & 80 & 80 & 80 & 80 & 75 & 75 & 70 & 75 & 75 & 80 & 76 \\
\hline Amanat & 70 & 70 & 75 & 70 & 70 & 70 & 70 & 70 & 70 & 70 & 70 & 70 & 70 & 70 & 70 & 70,3 \\
\hline Gaya Bahasa & 70 & 70 & 70 & 70 & 70 & 70 & 75 & 75 & 70 & 65 & 60 & 65 & 70 & 70 & 70 & 69,3 \\
\hline
\end{tabular}

Dari data di atas, dapat terlihat bahwa beberapa unsur interinsik mengalami peningkatan yang yaitu, pada unsur tema, dari rata-rata 60,6 menjadi 69 (berdasarkan konversi maka, nilai D naik menjadi C). Untuk unsur latar, siklus awal 62 dan meningkat menjadi 74.3. kemampuan menganalisis tokoh dan penokohan dalam cerita juga mengalami peningkatan dari 62,7 menjadi 72,7. Saat meneliti alur, mahasiswa sudah mengalami sedikit peningkatan dari 59,7 menjadi 69,3. Sudut pandang meningkat dari 62,7 menjadi 76. Unsur amanat pun naik dari 63 menjadi 70,3. Dan gaya Bahasa meningkat dari 61,7 menjadi 69,3.

Dari data diatas dapat disimpulkan bahwa, pada siklus 2 terjadi peningkatan yang terjadi, sehingga, pada unsur sudut pandang, mahasiswa dinilai telah cukup baik dalam mengerti unsur interinsik sebuah karya satra yaitu pada unsur sudut pandang. Namun untuk unsur lain, nilai mahasiswa belum memenuhi standard kompetensi dalam menganalisis unsur interinsik sebuah karya sastra. 


\section{JURNAL ILMIAH \\ BINA EDUKASI \\ ISSN 1979-8598 E-ISSN: 2655-8378 \\ http://journal.binadarma.ac.id/index.php/jurnalbinaedukasi \\ Vol. 14, No. 1, Juni 2021, $69-80$}

\subsection{Siklus 3}

Pada siklus ini, merupakan siklus teerakhir dalam PTK.. Observer dan pengajar kali ini mengevaluasi dan mengamati lebih dalam dari apa yang dilakukan selama siklus kedua. Kemampuan mahasiswa meningkat lebih baik walaupun belum signifikan, karena ada beberapa unsur interinsik masih masuk kedalam zona cukup (65-74). Sehingga dibutuhkan usaha yang lebih baik untuk meningkatkan kemampuan mahasiswa. Hal pertama yang harus diubah adalah, materi belajar. Novel memiliki cerita yang kompleks, sehingg pengajar dan pengawas memutuskan untuk mengganti materi belajarnya menjadi cerita pendek, namun cerpen yang diberi haruslah yang memiliki ide cerita kompleks sehingga dapat memicu mahasiswa untu berpikir kritis.

Tabel 5. Nilai Rata-rata Analisis Unsur Interinsik Mahasiswa Siklus 3

\begin{tabular}{|c|c|c|c|c|c|c|c|c|c|c|c|c|c|c|c|c|}
\hline \multirow{2}{*}{$\begin{array}{c}\text { Unsur } \\
\text { Interinsik }\end{array}$} & \multicolumn{15}{|c|}{ Mahasiswa } & \multirow{2}{*}{$\begin{array}{l}\text { Rata- } \\
\text { Rata }\end{array}$} \\
\hline & $\mathrm{A}$ & $\mathrm{B}$ & $\mathrm{C}$ & $\mathrm{D}$ & $\mathrm{E}$ & $\mathrm{F}$ & $\mathrm{G}$ & $\mathrm{H}$ & I & $\mathrm{J}$ & $\mathrm{K}$ & $\mathrm{L}$ & $\mathrm{M}$ & $\mathrm{N}$ & $\mathrm{O}$ & \\
\hline Tema & 80 & 80 & 80 & 80 & 85 & 85 & 80 & 70 & 85 & 90 & 80 & 80 & 75 & 75 & 85 & 80,7 \\
\hline Latar & 90 & 90 & 85 & 85 & 80 & 90 & 90 & 90 & 90 & 85 & 80 & 80 & 85 & 80 & 85 & 85,7 \\
\hline $\begin{array}{l}\text { Tokoh dan } \\
\text { Penokohan }\end{array}$ & 85 & 85 & 85 & 85 & 85 & 85 & 85 & 85 & 85 & 85 & 85 & 85 & 85 & 85 & 85 & 85 \\
\hline Alur & 85 & 80 & 80 & 80 & 90 & 80 & 85 & 80 & 80 & 75 & 80 & 75 & 75 & 75 & 85 & 80 \\
\hline Sudut Pandang & 75 & 75 & 75 & 75 & 75 & 90 & 90 & 90 & 90 & 85 & 80 & 70 & 85 & 85 & 90 & 82 \\
\hline Amanat & 80 & 80 & 75 & 75 & 75 & 75 & 80 & 80 & 80 & 80 & 80 & 80 & 80 & 80 & 80 & 78,7 \\
\hline Gaya Bahasa & 80 & 80 & 80 & 80 & 80 & 80 & 80 & 80 & 80 & 80 & 80 & 80 & 80 & 80 & 80 & 80 \\
\hline
\end{tabular}

Pada siklus ke-3, peneliti memilih cerpen yang memiliki cerita bagus agar dapat mengembangkan kemampuan berpikir kritis mahasiswa. Cerpen diyakini dapat lebih dipahami karena lebih pendek dan hanya berfokus pada 1 cerita. Setelah memberikan asesmen pada siklus ini, dan berdasarkan pengamatan, terdapat peningkatan yang cukup signifikan, bahkan pada unsur latar dan tokoh dan penokohan, nilai yang didapat mencapai nilai A (85-100). Sedangkan untuk unsur lain seperti Tema, alur, gaya Bahasa, amanat, dan sudut pandang, telah meningkat dengan nilai B (75-84).

\section{SIMPULAN}

Penelitian ini merupakan penelitian tindakan kelas yang dilakukan untuk membantu meningkatkan kemampuan mahasiswa serta mengevaluasi metode pembelajaran yang diterapkan selama ini oleh pengajar. Diharapkan dalam penelitian seperti ini, akan dapat memperoleh pengamatan yang lebih serius terkait permasalahan belajar dan mengajar. Dalam pelaksanaan siklus 1, 2 dan 3 telah banyak diperoleh latar belakang permasalahan langsung didalam kelas, 


\section{JURNAL ILMIAH}

BINA EDUKASI

ISSN 1979-8598 E-ISSN: 2655-8378

http://journal.binadarma.ac.id/index.php/jurnalbinaedukasi

Vol. 14, No. 1, Juni 2021, 69-80

sehingga perbaikan yang dilakukan dalam setiap siklus menghasilkan peningkatan yang cukup signifikan sebagai salah satu alternatif pengajaran terhadap analisis karya sastra dengan menerapkan metode diskusi. Sesuai dengan kebaikan metode diskusi yang dikemukakan oleh sutomo dalam Surachmad (1997), yaitu mahasiswa mendapat kesempatan mengemukakan ide-idenya atau pola pikirnya dan mempertahankannya dengan argumentasi yang dapat dipertanggung jawabkan. Dalam diskusi setiap anak mendapat kesempatan untuk mengembangkan gagasannya terhadap masalah yang dihadapinya. Dan Mengembangkan cara berpikir siswa yang logis, kritis dan sikap menghargai pendapat orang lain. Diharapkan kedepan akan lebih banyak lagi penelitian yang dilakukan untuk meningkatkan kemampuan Analisa, berpikir kritis serta minat baca para pelajar. Semoga penelitian ini juga dapat menjadi referensi para peniliti yang akan meneliti tentang literasi. 


\section{DAFTAR PUSTAKA}

Abrams, M.H. (1981). A Glossary of Literary Terms. Boston, Massachusetts: Heinle \& Heinle.

Harsanti, A.G. (2015). Pendidikan Karakter melalui Pembelajaran Sastra. https://www.google.com/url? sa $=t \& r c t=j \& q=\&$ esrc $=s \&$ source $=$ web $\& c d=\& v e d=2 a h U K E w j G O O f C h M L x A h V U f X O K H W P J D U M Q F j A A e g Q I A x A$ D\&url=https\%3A\%2F\%2Fjurnal.unej.ac.id. Diunduh tanggal 10 Juni 2021.

Kenny. (1996). Sastra dan Tekniknya. Jakarta: Nunang Jaya.

Kemmis, S \& McTaggart, R. (1998). The Action Research Planner, Third Edition. Victoria: Deakin University.

Nurgiyantoro, B. (2009). Teori Pengkajian Fiksi. Yogyakarta: Gajah Mada University Press.

Nurhalim, K. (2000). Prosedur Pelaksanaan PTK. Universitas Negeri Semarang.

Rahmanto, B. 2005. Metode Pengajaran Sastra. Yogyakarta: Kanisius.

Siswandarti. (2009). Panduan Belajar Bahasa Indonesia untuk SMA kelas XI. Yogyakarta: Dinas Pendidikan Menengah dan Nonformal Kabupaten Bantul.

Sudjana. (2001). Media Pengajaran. Bandung: Sinar Baru Algensindo.

Surachmad, W. (1997). Pengantar Penelitian Ilmiah, Tarsito, Bandung 